\title{
Molecular Cloning and Expression in Escherichia coli of the rec $A$ Gene of Legionella pneumophila
}

\author{
By LAWRENCE A. DREYFUS \\ Department of Microbiology, The University of Texas Medical Branch, Galveston, \\ Texas 77550, USA
}

(Received 20 July 1989; accepted 11 August 1989)

\begin{abstract}
Interspecific complementation of an Escherichia coli recA mutant with a Legionella pneumophila genomic library was used to identify a recombinant plasmid encoding the $L$. pneumophila rec $A$ gene. Recombinant $E$. coli strains harbouring the $L$. pneumophila rec $A$ gene were isolated by replica-plating bacterial colonies on medium containing methyl methanesulphonate (MMS). MMS-resistant clones were identified as encoding the $L$. pneumophila $\operatorname{rec} A$ analogue by their ability to protect $E$. coli $\mathrm{HB} 101$ from UV exposure and promote homologous recombination. Subcloning of selected restriction fragments and $\mathrm{Tn} 5$ mutagenesis localized the $\operatorname{rec} A$ gene to a $1.7 \mathrm{~kb} B g / \mathrm{II}-E c o$ RI fragment. Analysis of minicell preparations harbouring a $1.9 \mathrm{~kb} E c o \mathrm{RI}$ fragment containing the $r e c A$ coding segment revealed a single $37.5 \mathrm{kDa}$ protein. Insertional inactivation of the cloned $\operatorname{rec} A$ gene by $\operatorname{Tn} 5$ resulted in the disappearance of the $37.5 \mathrm{kDa}$ protein, concomitant with the loss of RecA function. The $L$. pneumophila recA gene product did not promote induction of a $\lambda$ lysogen; instead, the presence of the heterologous rec $A$ gene caused a significant reduction in spontaneous and mitomycin-C-induced prophage induction in $\mathrm{rec} \mathrm{A}^{+}$ and rec $A E$. coli backgrounds. Despite the lack of significant genetic homology between the $L$. pneumophila rec $A$ gene and the $E$. coli counterpart, the $L$. pneumophila RecA protein was nearly identical to that of $E$. coli in molecular mass, and the two proteins showed antigenic crossreactivity. Western blot analysis of UV-treated $L$. pneumophila revealed a significant increase in RecA antigen in irradiated versus control cells, suggesting that the $L$. pneumophila rec $A$ gene is regulated in a manner similar to that of $E$. coli rec $A$.
\end{abstract}

\section{INTRODUCTION}

Legionella pneumophila is a Gram-negative bacterium widely distributed in natural and manmade fresh-water habitats (Fliermans et al., 1981; Stout et al., 1982). To date, a growing list of related Legionella species comprising at least 33 serogroups have been classified (Thacker et al., 1985). Results from DNA-DNA hybridization experiments suggest that the Legionellaceae are unrelated to other known bacterial families (Brenner et al., 1979, 1981). In contrast to our increasing understanding of the bacteriology and ecology of this group of bacteria, basic information on the genetic organization and gene expression in L. pneumophila is currently lacking.

Recombination-deficient $\left(\operatorname{Rec}^{-}\right)$L. pneumophila strains would be a valuable tool in developing methods to genetically characterize metabolic and pathogenic properties of $L$.pneumophila. The availability of $\operatorname{Rec}^{-}$L. pneumophila strains would permit a number of currently difficult or impossible methodologies including: (1) stable maintenance of $R^{\prime}$ plasmids resulting from in vivo cloning, (2) recovery from $L$. pneumophila recipient strains of cloned genes mobilized from Escherichia coli-based gene libraries, and (3) an analysis of the recombinational requirements 
associated with the reversible phenotypic conversion between virulent and avirulent isolates (Elliot \& Johnson, 1982; McDade \& Shephard, 1979).

Homologous recombination in $E$. coli is controlled in part by the rec $A$ gene product (Clark, 1973). The RecA protein possesses a variety of regulatory and catalytic activities involved in homologous recombination, DNA repair mechanisms, and induction of prophage $\lambda$ (McEntee $e t$ al., 1979; Roberts et al., 1978; Walker, 1984). Recently, recA gene analogues from a number of bacteria have been identified by heterospecific complementation of recA mutations in $E$. coli (Better \& Helinski, 1983; Finch et al., 1986; Geoghegan \& Houghton, 1987; Goldberg \& Mekalanos, 1986; Keener et al., 1984; Koomey \& Falkow, 1987; Ohman et al., 1985). In this report I describe the cloning, characterization and expression in $E$. coli of the rec $A$ analogue of $L$. pneumophila, and demonstrate that the $L$. pneumophila rec $A$ gene product possesses considerable functional and antigenic similarity to its $E$. coli counterpart. In addition, the $L$. pneumophila rec $A$ gene appears to be induced by UV treatment.

\section{METHODS}

Bacterial strains, bacteriophage and plasmids. These are listed in Table 1.

Media. L. pneumophila was grown in liquid and on solid buffered charcoal yeast extract medium (BCYE) (Edelstein, 1981). E. coli strains were grown in L-medium or M9 or M63 minimal media (Maniatis et al., 1982). Antibiotics used for $E$. coli selection were at the following concentrations in $\mu \mathrm{g} \mathrm{ml}^{-1}$ : carbenicillin $(\mathrm{Cb}), 100$;

Table 1. Bacterial strains, bacteriophage and plasmids

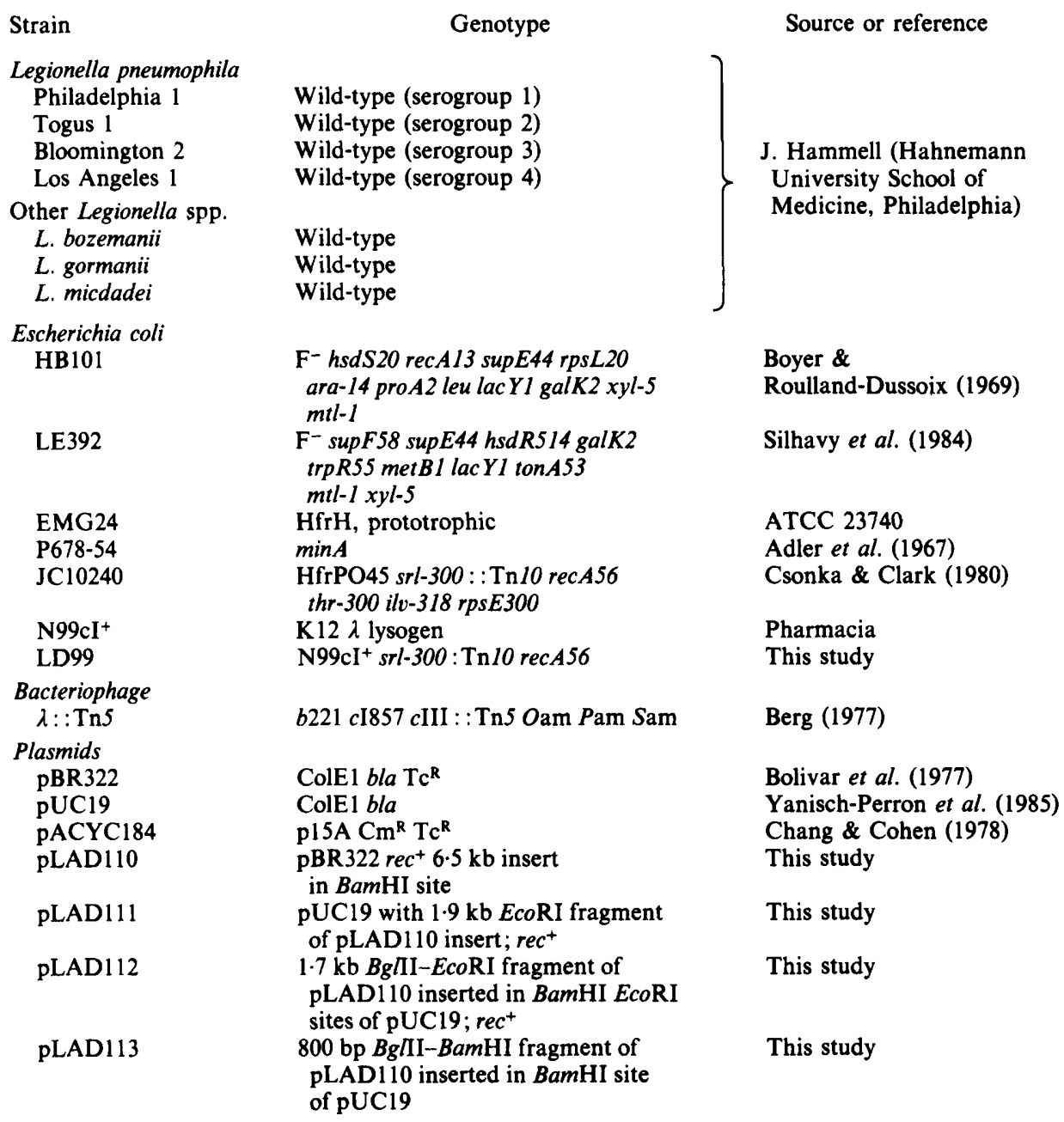


kanamycin $(\mathrm{Km}), 50$; and tetracycline (Tc), 10. Medium containing methyl methanesulphonate (MMS) was prepared by spreading $0.1 \mathrm{ml}$ of $2 \%(\mathrm{v} / \mathrm{v})$ solution on the surface of L-agar plates.

General recombinant DNA methods. Large-scale plasmid DNA was prepared by a cleared lysate method (Clewell \& Helinski, 1969) and purified by $\mathrm{CsCl}$ density-gradient centrifugation in the presence of ethidium bromide (Stougaard \& Molin, 1981). Small-scale plasmid preparations were performed by the method of Holmes \& Quigley (1981). Restriction endonuclease digests of plasmid DNA were performed according to the manufacturer's specifications. DNA fragments were analysed by electrophoresis through agarose or acrylamide gels containing TBE buffer (0.089 M-Tris pH 8.0, 0.089 M-boric acid, 0.002 M-EDTA) and ethidium bromide $\left(0.5 \mu \mathrm{g} \mathrm{ml}^{-1}\right)$. Physical mapping of recombinant plasmids was performed by single and multiple restriction enzyme digestion followed by electrophoresis in agarose or acrylamide gels. The positions of $\mathrm{Tn} 5$ insertions in recombinant plasmids were located by examining the resulting alteration in the restriction digestion pattern based on a published map of Tn5 (Jorgensen et al., 1979). Chromosomal DNA was purified as described by Goldberg \& Ohman (1984).

Construction of an L. pneumophila genomic library. High-molecular-mass L. pneumophila Philadelphia 1 DNA $(50 \mu \mathrm{g})$ was partially digested with $S a u 3 A$ to generate fragments predominantly $4-10 \mathrm{~kb}$ in length. The resulting genomic DNA fragments and molecular mass standards (HindIII digested $\lambda$ DNA) were separated by electrophoresis through a $0.6 \%(\mathrm{w} / \mathrm{v})$ agarose gel $(20 \times 20 \mathrm{~cm})$ for $13 \mathrm{~h}$ at $2 \mathrm{~V} \mathrm{~cm}^{-1}$. Following electrophoresis, the outer gel lanes containing the molecular mass standards were sliced from the gel, stained in ethidium bromide $\left(0.5 \mu \mathrm{g} \mathrm{ml}^{-1}\right)$, rinsed free of excess dye, and repositioned beside the gel slab on a UV transilluminator. The gel slab was protected from direct UV exposure by aluminium foil. Exposure of stained size markers to UV light located the region of the gel slab containing fragments ranging in size from 4 to $8 \mathrm{~kb}$. The appropriate portion of the gel was excised with a clean razor and placed in as many $17 \times 100 \mathrm{~mm}$ polypropylene snap-cap tubes as required. The agarose was mashed with a sterile glass rod, mixed with an equal volume of phenol (Aldrich) previously redistilled

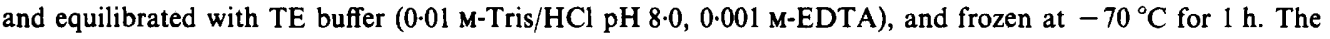
$\mathrm{gel} /$ phenol mixture was centrifuged at $15000 \mathrm{~g}$ in a Sorvall SM-24 rotor for $30 \mathrm{~min}$ to separate the phases. The aqueous phase was removed and re-extracted with phenol as just described followed by two consecutive extractions with chloroform/isoamyl alcohol $(24: 1, \mathrm{v} / \mathrm{v})$. The partially digested chromosomal DNA was then precipitated with ethanol in the presence of $2 \mathrm{M}$-ammonium acetate. The precipitated DNA was collected by centrifugation, washed with $70 \%(\mathrm{v} / \mathrm{v})$ ethanol, and desiccated until dry. The dried DNA pellet was dissolved in $0.1 \mathrm{ml} \mathrm{TE}$ and stored at $4{ }^{\circ} \mathrm{C}$ for no longer than two weeks.

Vector DNA (pBR322) was prepared as described above. Following digestion with BamHI, linearized pBR322 was dephosphorylated with calf intestinal phosphatase (Boehringer Mannheim Biochemicals). Phosphatase was removed from the reaction mixture by heating at $68^{\circ} \mathrm{C}$ in the presence of $0.01 \mathrm{M}$-EDTA for $15 \mathrm{~min}$, followed by two extractions with TE-saturated phenol, then chloroform/isoamyl alcohol $(24: 1, \mathrm{v} / \mathrm{v})$. Dephosphorylated pBR322 and partially digested chromosomal DNA were mixed at a molar ratio of $1: 2$ (vector : insert) with T4 DNA ligase (Pharmacia), and incubated for $4 \mathrm{~h}$ at room temperature, followed by $18 \mathrm{~h}$ at $4{ }^{\circ} \mathrm{C}$. Portions of the ligation mixture were used to transform $\mathrm{CaCl}_{2}$-treated $E$. coli $\mathrm{HB} 101$. Transformants were selected on L-agar plates containing $\mathrm{Cb}$. The entire library was spread in $0.1 \mathrm{ml}$ volumes on $\mathrm{L}$-agar containing $\mathrm{Cb}$, and following overnight incubation the resulting bacterial colonies (about 200 per plate) were washed from 100 plates in L-broth, pelleted by centrifugation and resuspended to one-half the original volume in L-medium containing $50 \%(\mathrm{v} / \mathrm{v})$ glycerol. The bacterial suspension was then stored in $1 \mathrm{ml}$ portions at $-70^{\circ} \mathrm{C}$.

Transposon mutagenesis of cloned DNA. Tn 5 was transferred from $\lambda::$ Tn 5 to a recombinant-plasmid-containing

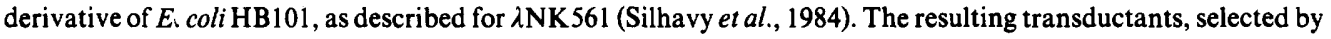
plating on $\mathrm{Km}$-containing L-agar, were spread at a density of 300-500 c.f.u. per plate. Following overnight growth, colonies washed from 20 plates were pooled and a portion then used as inoculum for 1 litre of $L$-medium (with $\mathrm{Km}$ ) contained in a 2.8 litre Fernbach flask. The culture was grown overnight at $37^{\circ} \mathrm{C}$ with vigorous aeration then used as a source of plasmid DNA. Plasmid molecules which contained $\operatorname{Tn} 5$ insertions were identified by transformation of competent $E$. coli $\mathrm{HB} 101$ followed by selection for resistance to $\mathrm{Km}$. $\mathrm{Km}^{\mathrm{R}}$ colonies were then screened for the loss of $\operatorname{rec} A$ function by sensitivity to MMS and UV light.

$U V$ irradiation. Sensitivity to UV exposure was tested by plating appropriate dilutions of mid-exponential-phase cultures on agar plates and exposing them to UV light at the indicated doses. UV dose was determined with a UV dosimeter. Alternatively, RecA activity was tested by shielding from the UV one half of an agar plate crossstreaked with single colonies from strains to be tested. Following UV exposure $\left(10 \mathrm{~J} \mathrm{~m}^{-2}\right)$, plates were wrapped to prevent photoreactivation and incubated at $37^{\circ} \mathrm{C}$.

Minicell analysis. Minicells were prepared from plasmid-containing derivatives of E. coli P678-54 and labelled with $\left[{ }^{35}\right.$ S]methionine (ICN Radiochemicals) as described by Goldberg \& Mekalanos (1986). SDS extracts of labelled minicells were separated by electrophoresis through $12.5 \%(\mathrm{w} / \mathrm{v})$ acrylamide gels (Laemmli, 1970), stained to localize size markers, then dried under a vacuum at $80^{\circ} \mathrm{C}$. Dried gels were exposed to X-OMAT AR film (Eastman Kodak) for $24-36 \mathrm{~h}$ to visualize radiolabelled protein bands.

Bacterial conjugation. Cultures of $E$. coli EMG24 and plasmid-containing derivatives of $E$. coli HB101 were grown to mid-exponential phase in L-medium (or L-medium with added $\mathrm{Cb}$ ) from overnight starter cultures, then 
washed twice in L-medium to remove antibiotic from the HB101 strains. Samples $\left(1 \mathrm{ml}, 5 \times 10^{7}\right.$ c.f.u. $)$ of EMG24 (donor) and $\mathrm{HBl} 101$ (recipient) strains were mixed, incubated at $37^{\circ} \mathrm{C}$ for $1 \mathrm{~h}$, then washed three times in sterile saline to remove L-medium components. The washed mating mixture was then plated on $\mathrm{M} 9$ minimal medium containing either leucine or proline, each at $100 \mu \mathrm{g} \mathrm{ml}^{-1}$, and $\mathrm{Cb}$ to counterselect donor strains. The frequency of recombination in plasmid-containing HB101 strains was determined.

Induction of prophage $\lambda$. Plasmid-containing derivatives of two $E$. coli $\lambda$ lysogens, $\mathrm{N} 99 \mathrm{cI}^{+}\left(\mathrm{Rec}^{+}\right)$and LD99 (rec $A 56)$, were grown at $37^{\circ} \mathrm{C}$ to mid-exponential phase in L-medium and induced by the addition of mitomycin $\mathrm{C}$ $\left(10 \mu \mathrm{g} \mathrm{ml}^{-1}\right)$. After $1 \mathrm{~h}$ incubation in the presence of mitomycin $\mathrm{C}, 1 \mathrm{ml}$ samples of each culture were removed and lysed by the addition of chloroform $(0.02 \mathrm{ml})$. The lysed culture samples were centrifuged for $1 \mathrm{~min}$ in a microcentrifuge to remove cell debris, and the resulting supernatant fraction was titrated for $\lambda$ on a lawn of $E$. coli LE392. Strain LD99 was constructed by mating N99 $\mathrm{CI}^{+}$with JC10240, selecting for the inheritance of tetracycline resistance, and then screening for the loss of sorbitol utilization (Csonka \& Clark, 1980).

Preparation of anti-RecA antibody. Two female New Zealand White rabbits were immunized with $500 \mu \mathrm{g}$ each of purified E. coli RecA protein (US Biochemical Corp.) emulsified in Freund's complete adjuvant $(1.0 \mathrm{ml})$ in a total volume of $2.0 \mathrm{ml}$. Several (8-10) subcutaneous injections were made along the back of each rabbit, each delivering approximately $0.1 \mathrm{ml}$ of immunogen. The remainder of the immunogen $(200-250 \mu \mathrm{g})$ was administered intramuscularly in a hind quarter. At monthly intervals, two successive booster immunizations were given to the rabbits as just described except that the RecA protein was emulsified in Freund's incomplete adjuvant. One week after the second booster immunization, blood was drawn from the rabbits and sera prepared. Anti-RecA antibody was assessed by Western blot analysis (Towbin et al., 1979). The anti-RecA antibody titre of the pooled sera exceeded 10000.

Induction of the Legionella recA gene. Two $10 \mathrm{ml}$ samples of a mid-exponential-phase culture of $L$.pneumophila in BCYE broth (about $1 \times 10^{8} \mathrm{ml}^{-1}$ ) were harvested by centrifugation at $5000 \mathrm{~g}$ for $10 \mathrm{~min}$, washed in normal saline and resuspended in $1 \mathrm{ml}$ saline. The bacterial suspensions were each placed in the bottom of $30 \mathrm{~mm}$ sterile Petri plates and one was irradiated with UV $\left(10 \mathrm{~J} \mathrm{~m}^{-2}\right)$ from a germicidal lamp. The control suspension received no UV treatment. The suspensions were transferred to $250 \mathrm{ml}$ shake flasks containing $50 \mathrm{ml}$ pre-warmed BCYE broth and incubated with shaking $\left(200\right.$ r.p.m.) for $1 \mathrm{~h}$ at $37^{\circ} \mathrm{C}$. Following incubation, the bacterial cells were pelleted by centrifugation as above, resuspended in $0.1 \mathrm{ml}$ sterile water, and prepared for SDS-PAGE by the addition of $2 \times$ sample buffer containing $10 \%(\mathrm{v} / \mathrm{v}) 2$-mercaptoethanol followed by boiling for $10 \mathrm{~min}$. Samples $(10 \mu \mathrm{l})$ of each preparation were fractionated by SDS-PAGE on a $12.5 \%$ acrylamide gel as described above, transferred to nitrocellulose by electroblotting and probed with the anti-RecA antibody preparation. Alkalinephosphatase-conjugated goat anti-rabbit IgG (Promega) served as the second antibody. The relative quantity of RecA protein in control and experimental gel lanes was determined by scanning the Western blot with a model GS 300 transmittance/reflectance scanning densitometer (Hoeffer Scientific Instruments).

Southern blot analysis. This was done as described by Silhavy et al. (1984). Genomic digests were separated on a $0.7 \%$ agarose gel, transferred to nitrocellulose and probed with a ${ }^{32} \mathrm{P}$-labelled, nick-translated DNA probe. Hybridization was performed at $42{ }^{\circ} \mathrm{C}$ in $50 \%(\mathrm{w} / \mathrm{v})$ formamide, $5 \times \mathrm{SSC}(\mathrm{pH} 7 \cdot 0), 5 \times$ Denhardt's, $0 \cdot 1 \% \mathrm{SDS}$, and $0.1 \mathrm{mg}$ denatured salmon sperm DNA ml- $\mathrm{m}^{-1}$ SSC $(1 \times)$ is $0.15 \mathrm{M}-\mathrm{NaCl}, 0.015 \mathrm{M}$-sodium citrate $(\mathrm{pH} 7.0)$. Denhardt's reagent $(1 \times)$ is $0.02 \%$ Ficoll, $0.02 \%$ bovine serum albumin, and $0.02 \%$ polyvinylpyrrolidone. Posthybridization washes were as follow: $2 \times 5 \mathrm{~min}$ in $1 \times \mathrm{SSC}, 0.1 \% \mathrm{SDS}$ at $25^{\circ} \mathrm{C} ; 2 \times 5 \mathrm{~min}$ in $0.1 \times \mathrm{SSC}, 0.1 \% \mathrm{SDS}$ at $42^{\circ} \mathrm{C}$; and $1 \times 5 \mathrm{~min}$ in $0.1 \times \mathrm{SSC}, 0.1 \% \mathrm{SDS}$ at $55^{\circ} \mathrm{C}$. Radioactive fragments were detected by exposure to $\mathrm{X}$-OMAT AR film.

\section{RESULTS}

\section{Isolation of the L. pneumophila recA gene}

Because of its $\operatorname{rec} A$ genotype, $E$. coli $\mathrm{HB101}$ is highly sensitive to UV light and chemical mutagens. This fact was exploited as a means to isolate the $L$. pneumophila rec $A$ analogue by interspecific complementation. Recombinant $E$. coli HB101 isolates which harboured the $L$. pneumophila rec $A$ gene were easily identified as those clones in which the $\mathrm{RecA}^{-}$phenotype was suppressed.

Approximately 10000 L. pneumophila gene library members were spread on L-agar plates at a density of about 250 per plate. The bacterial colonies were replica-plated onto L-agar medium containing MMS. Four colonies which showed MMS-resistant $\left(\mathbf{M M S}^{\mathrm{R}}\right)$ growth were picked from the appropriate master plates, streaked for isolation, and retested for their RecA phenotype. All four isolates conferred resistance to MMS and to an exposure of UV light which killed a pBR322-containing derivative of $E$. coli $\mathrm{HB} 101$.

Plasmid DNA isolated from the four putative $r e c A$ clones was used to transform competent $E$. coli HB101. The resulting transformants were tested for MMS resistance to ensure that the 


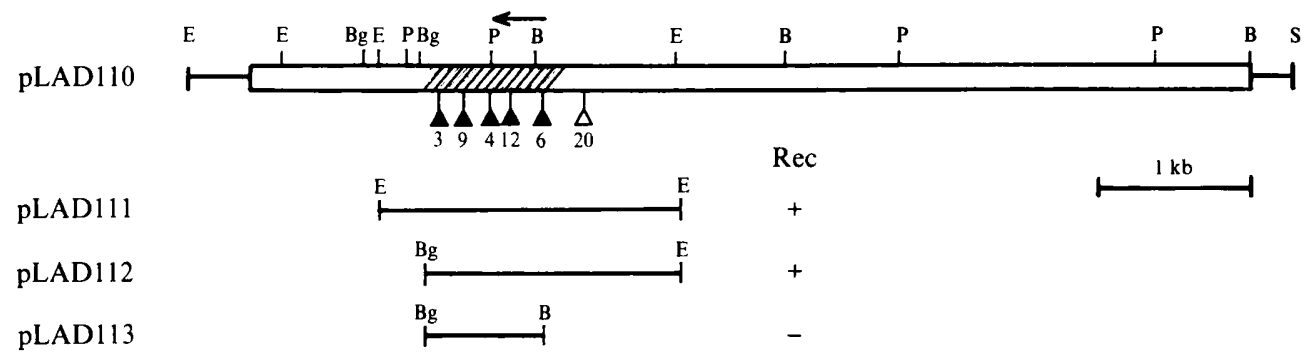

Fig. 1. Restriction map of the L. pneumophila DNA segment containing the recA gene. L. pneumophila DNA is designated by the boxed area; the pBR322 sequences of pLAD110 are defined by the thin lines. The position of $\operatorname{Tn} 5$ insertions which abolished the RecA ${ }^{+}$phenotype conferred by pLAD110 are designated by filled triangles. The open triangle shows the position of a $\operatorname{Tn} 5$ insertion which did not affect RecA activity. Plasmids pLAD111, pLAD112 and pLAD113 are pUC19 containing selected fragments of pLAD110 as shown. RecA activity of strains harbouring subcloned plasmids was assessed by UV sensitivity as described in Methods. The hatched area in the pLAD110 map denotes the approximate location of the $r e c A$ gene. The direction of $r e c A$ transcription is shown by the arrow above the gene map. Restriction enzyme abbreviations are: E, EcoRI; Bg, BglII; P, PstI ; B, BamHI; S, SalI.

observed RecA phenotype was linked to the recombinant plasmid and not due to spontaneous reversion of the $E$. coli $r e c A$ mutation. Transformants containing the putative $L$. pneumophila $r e c A$ gene sequences from all four original clones conferred resistance to MMS.

\section{Mapping, subcloning, and transposon mutagenesis of the L. pneumophila recA gene}

Restriction analysis of plasmid DNA from the MMS $^{\mathrm{R}}$ isolates revealed that the four recombinant plasmids contained identical $6.5 \mathrm{~kb}$ inserts of $L$. pneumophila DNA. A restriction map of one of these plasmids, called pLAD1 10, is shown in Fig. 1. Transposon mutagenesis and subcloning of selected restriction fragments were used to determine the approximate location of the $\operatorname{rec} A$ gene on the $6.5 \mathrm{~kb}$ insert of pLAD110. Sixteen Tn 5 inserts which abolished the Rec $A^{+}$ phenotype were shown to map in a $700 \mathrm{bp}$ region of pLAD110. The locations of representative inserts, including the two which mapped furthest apart ( 3 and 6) yet still within the putative rec $A$ coding region, are shown in Fig. 1. Of ten Tn 5 inserts which did not affect the RecA phenotype of pLAD110, the one which mapped closest to the cluster of inserts within the rec $A$ gene mapped approximately $270 \mathrm{bp}$ to the right of insert number 6 (Fig. 1). Since RecA activity was expressed by a $1.7 \mathrm{~kb} B g / \mathrm{II}-E c o$ RI subclone (pLAD112), the left end of the $r e c A$ gene resides between the Tn5 insert number 3 and the BglII site defined by the subclones pLAD112 and pLAD113.

\section{Expression of the L. pneumophila recA gene in E. coli}

Having isolated and mapped the L. pneumophila rec $A$ gene, experiments were done to further characterize the RecA phenotype conferred by pLAD110 and derivative recombinant plasmids.

The degree of UV sensitivity of the recA strain $E$. coli $\mathrm{HB} 101$ harbouring various plasmids is illustrated in Fig. 2. HB101(pLAD110) showed approximately $10^{5}$-fold higher resistance than $\mathrm{HB} 101$ (pBR322) to a comparable UV exposure (Fig. 2). Inactivation of MMS resistance by Tn5 insertion in pLAD1 10 also resulted in sensitivity to UV exposure. Strain HB101 (pLAD1 10.5-3), containing a $\operatorname{Tn} 5$ insertion mapping within the rec $A$ gene of pLAD110 $(\operatorname{Tn} 5$ insert number 3 in Fig. 1), displayed UV sensitivity approximately equivalent to that of HB101(pBR322) (Fig. 2). In contrast, a Tn 5 insertion which mapped outside the rec $A$ coding region, as in pLAD1 10.5-20, had no effect on the UV resistance expressed by HB101(pLAD110) (Fig. 2).

In addition to induction of DNA repair mechanisms, the $\operatorname{rec} A$ gene of $E$. coli plays a mandatory role in homologous recombination. To further characterize functional characteristics of the L. pneumophila rec $A$ gene product, its ability to promote recombination in $E$. coli HB101 was tested. The results of recombination between a prototrophic $E$. coli $\mathrm{HfrH}$ strain (EMG24) and plasmid-containing derivatives of HB101 are shown in Table 2. Recombination 


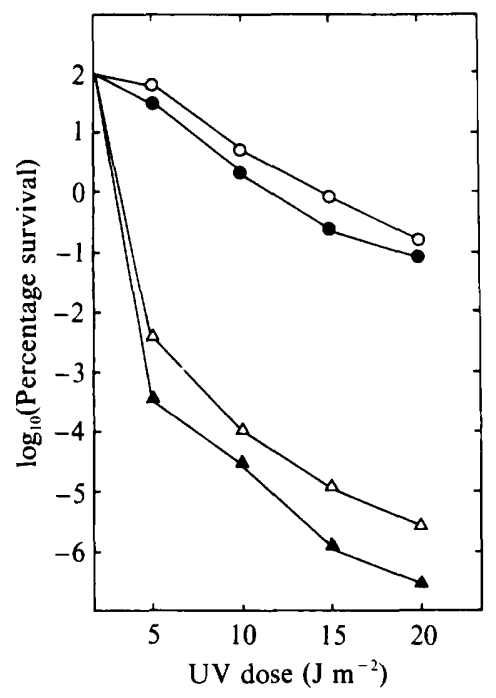

Fig. 2. Survival of various plasmid-containing isolates of $E$. coli HB101. Bacterial strains were irradiated with various doses of UV light, then survival was measured and expressed as a percentage of the value for the appropriate non-irradiated control strain. Symbols represent HB101 harbouring the following plasmids:O, pLAD110; $\bullet$, pLAD110.5-20; $\triangle$, pLAD110.5-3; $\Delta$, pBR322.

\section{Table 2. Recombination in E. coli strains}

Recipient strains were incubated with HfrH strain EMG24 for $1 \mathrm{~h}$ prior to plating on the appropriate minimal medium. Frequency is expressed as the number of recombinants per donor.

\begin{tabular}{lcr} 
Recipient & $\overbrace{\text { Pro }^{+}}^{\text {Frequency of recombinants }}$ & \multicolumn{1}{c}{ Leu $^{+}$} \\
HB101(pBR322) & $2 \times 10^{-6}$ & $9 \times 10^{-6}$ \\
HB101(pLAD110) & $7.1 \times 10^{-3}$ & $1.1 \times 10^{-2}$ \\
HB101(pLAD110.5-3) & $1 \cdot 1 \times 10^{-6}$ & $3 \times 10^{-7}$ \\
HB101(pLAD110.5-20) & $1.2 \times 10^{-3}$ & $2.3 \times 10^{-2}$
\end{tabular}

between EMG24 and HB101(pLAD110) or HB101(pLAD110.5-20) was approximately $10^{3}$-fold greater than that observed when HB101(pBR322) or HB101(pLAD110.5-3) were used as recipient strains. Low-level recombination between EMG24 and HB101 in the absence of a functional $\mathrm{rec} A$ gene was attributed to $\mathrm{F}^{\prime}$ formation.

Cleavage of LexA and $\lambda$ repressor proteins in $E$. coli requires a normally quiescent proteolytic activity of the RecA protein. Expression of this activity is mediated by a number of chemical and physical treatments and represents activation of the SOS response in E. coli. Cleavage of the $\lambda$ repressor by the $L$. pneumophila $\operatorname{RecA}$ protein was tested by assessing the induction of prophage $\lambda$ in plasmid-containing $\operatorname{rec} A$ and $\operatorname{rec} A^{+} E$. coli backgrounds. The addition of mitomycin $\mathrm{C}\left(10 \mu \mathrm{g} \mathrm{ml}^{-1}\right)$ to strain $\mathrm{N} 9 \mathrm{cI}^{+}\left(\mathrm{rec} A^{+}\right)$harbouring pUC19 resulted in a nearly 100 fold increase in $\lambda$ plaque production over the observed level of spontaneous induction (Table 3 ). The presence of the cloned $L$. pneumophila rec $A$ gene reduced the level of both spontaneous and mitomycin-C-induced prophage induction by nearly 100 -fold. In addition, the $L$. pneumophila $\operatorname{rec} A$ gene product failed to promote $\lambda$ induction in a $\operatorname{rec} A E$. coli background.

Identification of the L. pneumophila recA gene product and $U V$-induced synthesis of the RecA protein

Minicell analysis was used to investigate the product of the $L$. pneumophila recA gene. In an attempt to eliminate other $L$. pneumophila protein products which may be encoded on pLAD110, 
Table 3. Spontaneous and mitomycin- $C$-mediated induction of $\lambda$ prophage in plasmid-containing strains

\begin{tabular}{|c|c|c|}
\hline \multirow[b]{2}{*}{ Strain } & \multicolumn{2}{|c|}{$\begin{array}{l}\text { Prophage induction (p.f.u. } \mathrm{ml}^{-1} \text { ) following } \\
\text { treatment with: }\end{array}$} \\
\hline & No mitomycin C & $\begin{array}{l}\text { Mitomycin C } \\
\text { at } 10 \mu \mathrm{g} \mathrm{ml}^{-1}\end{array}$ \\
\hline N99cI+(pUC19) & $7.8 \times 10^{5}$ & $4.3 \times 10^{7}$ \\
\hline $\mathrm{N} 99 \mathrm{cI}^{+}(\mathrm{pLAD} 111)$ & $2.3 \times 10^{3}$ & $4.0 \times 10^{5}$ \\
\hline LD99(pUC19) & 100 & 100 \\
\hline LD99(pLAD1 11) & 0 & 0 \\
\hline
\end{tabular}

a $1.9 \mathrm{~kb} E c o \mathrm{RI}$ fragment containing the entire $L$. pneumophila recA gene was subcloned into the single EcoRI site of pACYC184. The resulting plasmid pLAD211 and the pACYC184 vector were used to transform the minicell-producing $E$. coli strain P678-54. Minicells were isolated from both plasmid-containing derivatives of P678-54 and labelled with [ ${ }^{35}$ S]methionine. Following SDS-PAGE of labelled cell extracts and autoradiography, a single $21 \mathrm{kDa}$ protein band representing the monomeric form of the pACYC184-encoded type I chloramphenicol acetyltransferase was observed in minicells containing only vector DNA (Fig. 3, lane A). In contrast, the pLAD211-containing minicell preparation contained a major $37.5 \mathrm{kDa}$ protein and a minor $35 \mathrm{kDa}$ protein band (Fig. 3, lane B). The $37.5 \mathrm{kDa}$ protein is nearly identical in molecular mass to the E. coli RecA protein (Sancar et al., 1980) and presumably is the $L$. pneumophila counterpart. The $35 \mathrm{kDa}$ protein is probably a product of proteolytic cleavage of the native RecA protein. A similar finding was reported for the recA gene product of Vibrio cholerae (Goldberg \& Mekalanos, 1986).

To determine whether the $37.5 \mathrm{kDa}$ protein was in fact the product of the $r e c A$ gene, proteins encoded by pLAD 110 and two Tn5-mutated, RecA ${ }^{-}$derivatives were examined by minicell analysis (Fig. 4). The $37.5 \mathrm{kDa}$ protein appeared only in ${ }^{35} \mathrm{~S}$-labelled extracts of the pLAD110containing strain (Fig. 4, lane A). Mutation of pLAD110 to the RecA- phenotype coincided with the disappearance of the $37.5 \mathrm{kDa}$ protein. This finding, although not indisputable, strongly suggested that the $37.5 \mathrm{kDa}$ protein was the product of the L. pneumophila recA gene. In place of the $37.5 \mathrm{kDa}$ protein, the RecA- mutants encoded the Tn5-derived $28000 \mathrm{kDa}$ aminoglycoside 3 '-phosphotransferase, the IS50R-encoded $54 \mathrm{kDa}$ and $58 \mathrm{kDa}$ P2 inhibitor and transposase, respectively (Johnson et al., 1982), and truncated versions of the RecA protein (Fig. 4 , lanes $\mathrm{B}$ and $\mathrm{C}$ ). The two Tn5-containing pLAD1 10 derivatives examined were those spaced farthest apart yet still within the $\operatorname{rec} A$ coding region (Fig. 1). The sizes of the truncated $\operatorname{Rec} A$ proteins encoded by pLAD110.5-3 and pLAD110.5-6 were consistent with rec $A$ transcription starting to the right of the BamHI site and proceeding towards the $B g / \mathrm{II}$ site, as shown by the arrow in Fig. 1. These data are also consistent with the cloned $\operatorname{rec} A$ gene being under control of an endogenous promoter, since the direction of $r e c A$ transcription in pLAD110 is opposite that of the interrupted tetracycline-resistance gene of pBR322.

Induction of the L. pneumophila rec $A$ gene was examined by Western blot analysis of extracts of UV-treated and control L. pneumophila cells, using antibody against $E$. coli RecA protein as probe. Irradiation of L. pneumophila with UV resulted in a significant increase in the level of the RecA protein present in cell extracts (Fig. 5). A scan of the blot indicated a four- to fivefold increase in detectable RecA in UV-irradiated cells. In addition to the $37.5 \mathrm{kDa}$ form of RecA, the $35 \mathrm{kDa}$ breakdown was also observed.

\section{Southern blot analysis}

Genomic digests of various strains of $L$. pneumophila and other Legionella species were analysed by Southern blotting to determine sequence relatedness of the cloned $\operatorname{rec} A$ gene to the analogous DNA segment in other strains. When probed with a ${ }^{32} \mathrm{P}$-labelled $1.9 \mathrm{~kb} E c o \mathrm{RI}$ fragment containing the recA gene of the L. pneumophila Philadelphia 1 strain (serogroup 1), 


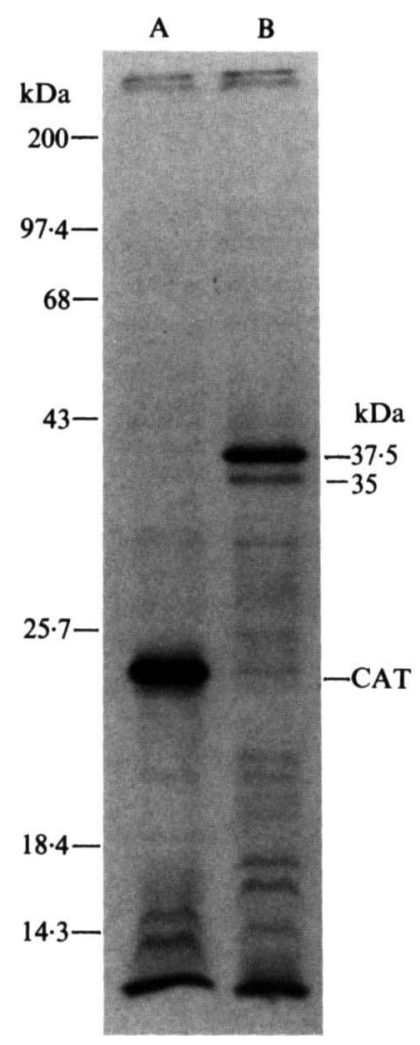

Fig. 3

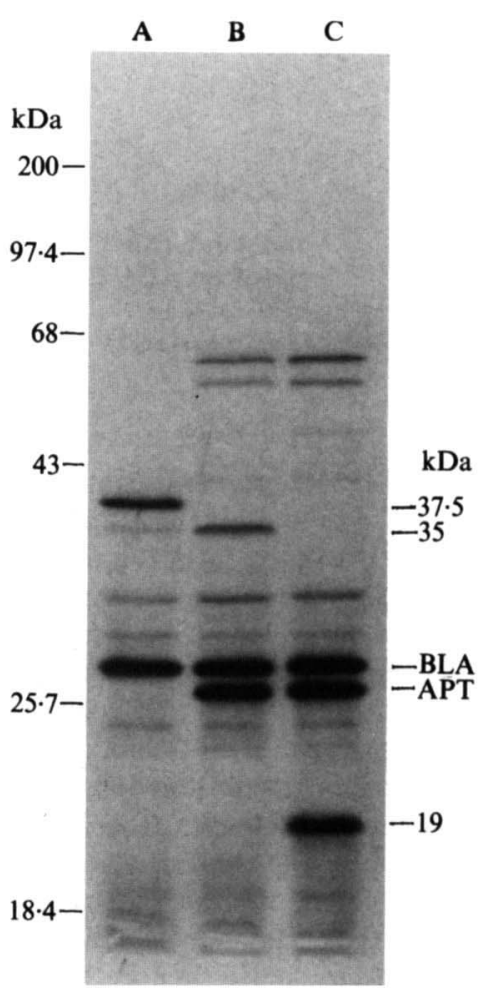

Fig. 4

Fig. 3. Expression of the L. pneumophila recA gene in minicells. Minicells were isolated and labelled with $\left[{ }^{35} \mathrm{~S}\right]$ methionine as described in Methods. SDS-soluble extracts of labelled minicell preparations were separated by electrophoresis through a $12.5 \%$ polyacrylamide gel. The gel was dried and exposed to X-ray film to produce the autoradiogram shown. Lane A, pACYC184; lane B, pLAD211. The position of molecular mass markers was determined by staining the gel prior to drying. Markers were: myosin (H-chain), $200 \mathrm{kDa}$; phosphorylase $b, 97.4 \mathrm{kDa}$; bovine serum albumin, $68 \mathrm{kDa}$; ovalbumin, $43 \mathrm{kDa} ; \alpha$-chymotrypsinogen, $25.7 \mathrm{kDa} ; \beta$-lactoglobulin, $18.4 \mathrm{kDa}$; lysozyme, $14.3 \mathrm{kDa}$. The type I chloramphenicol acetyltransferase encoded by pACYC184 is designated by CAT.

Fig. 4. Analysis of proteins encoded by pLAD110 and Tn5-interrupted derivatives. Minicell preparations, molecular mass standards, and conditions for preparing the autoradiogram from the dried polyacrylamide gel, were as described for Fig. 3. Lane A, pLAD110; lane B, pLAD110.5-3; lane C, pLAD110.5-6. Molecular mass values shown to the right are for the native RecA protein (37.5 kDa) and truncated derivatives $(35 \mathrm{kDa}$ and $19 \mathrm{kDa})$. The pBR322-encoded $\beta$-lactamase and the Tn5encoded aminoglycoside phosphotransferase are designated by BLA and APT, respectively.

EcoRI genomic digests of strains representing serogroups 1, 2, 3 and 4 yielded a single $1.9 \mathrm{~kb}$ band (Fig. 6, lanes 1-4). In contrast, a faint $6.0 \mathrm{~kb}$ fragment was seen in the lanes containing the non-pneumophila DNA digests (Fig. 6, lanes 5-7). The weak hybridization signal obtained with the non-pneumophila species suggests limited sequence relatedness between the recA gene of $L$. pneumophila and the three other Legionella species tested here. An EcoRI digest of E. coli genomic DNA did not hybridize with the L. pneumophila recA probe (Fig. 6, lane 8).

\section{DISCUSSION}

The rec $A$ gene participates in several important functions in $E$. coli, including homologous recombination, DNA repair and induction of the SOS response and prophage $\lambda$. In recent years, 


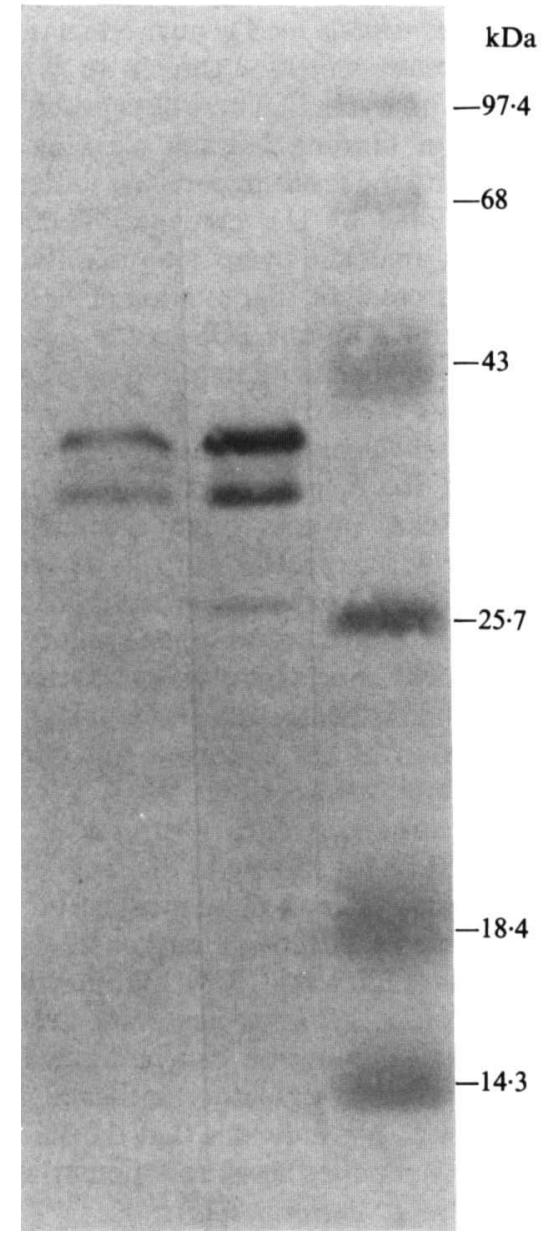

Fig. 5

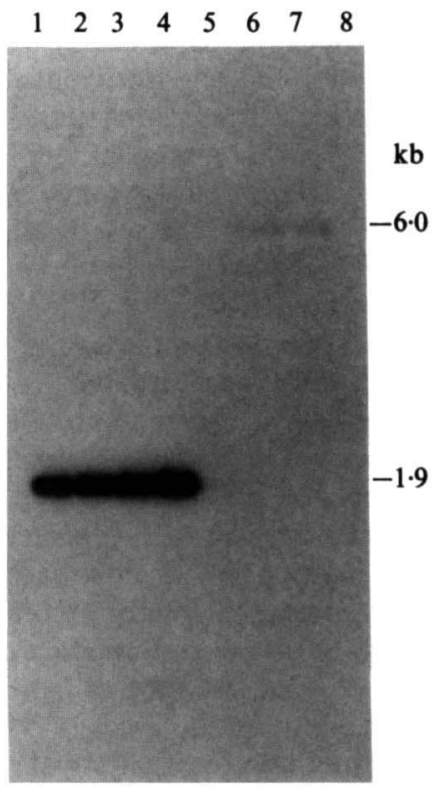

Fig. 6

Fig. 5. UV induction of L. pneumophila recA. Extracts of control (lane 1) and UV-treated (lane 2) $L$. pneumophila were separated by SDS-PAGE, electrotransferred to nitrocellulose and probed with antibody raised against $E$. coli RecA protein. Pre-stained molecular mass markers (lane 3) were: phosphorylase $b, 97.4 \mathrm{kDa}$; bovine serum albumin, $68 \mathrm{kDa}$; ovalbumin, $43 \mathrm{kDa}$; $\alpha$-chymotrypsinogen, $25.7 \mathrm{kDa} ; \beta$-lactoglobulin, $18.4 \mathrm{kDa}$ and lysozyme, $14.3 \mathrm{kDa}$.

Fig. 6. Southern blot analysis. EcoRI genomic digests of bacterial strains were separated by agarose gel electrophoresis, transferred to nitrocellulose, and hybridized with a ${ }^{32} \mathrm{P}$-labelled $1.9 \mathrm{~kb}$ DNA segment containing the entire $L$. pneumophila rec $A$ gene. Lanes $1-4$ contained 1-3 $\mu \mathrm{g}$ of DNA from $L$. pneumophila serogroups $1-4$, respectively. The remaining lanes contained identical preparations of DNA from $L$. bozemanii (lane 5), L. gormanii (lane 6), L. micdadei (lane 7), and E. coli (lane 8).

rec $A$ gene analogues from several widely divergent bacterial species have been cloned by complementation of $E$. coli recA mutations (see Introduction). A similar approach was used in this report to clone the $L$. pneumophila rec $A$ gene and partially characterize the encoded $\operatorname{Rec} A$ protein.

Heterologous recA genes described thus far promote homologous recombination and UV resistance in $E$. coli rec $A$ host strains. DNA repair and recombination promoting activities of the RecA proteins are thus highly conserved among widely divergent species. The ability to cleave $\lambda$ cI and induce SOS repair mechanisms, however, are properties thus far not reported with 
heterologous $r e c A$ products apart from RecA proteins of other members of the Enterobacteriaceae (Keener et al., 1984). With regard to cI cleavage, the $L$. pneumophila rec $A$ gene product is no exception to this observation. In fact, the presence of the L. pneumophila recA gene in an E. coli strain lysogenic for $\lambda$ resulted in an inhibition of induction by mitomycin $C$. These data probably indicate that the $L$. pneumophila RecA protein is capable of binding but not cleaving or inactivating cI. UV induction of the $L$. pneumophila rec $A$ gene and the resulting increase in RecA protein indicates that the $L$. pneumophila rec $A$ gene is regulated by UV damage. Whether regulation of $L$. pneumophila recA involves cleavage of a LexA analogue by an activated RecA protein, however, is not known. The inability to demonstrate proteolytic inactivation of $\lambda \mathrm{cI}$ by the $L$. pneumophila recA product is not necessarily indicative of a unique SOS-like response. Rather, these data are probably a reflection of the high degree of specificity required by $E$. coli RecA to bind and cleave cI.

Kokjohn \& Miller (1987) reported that the product of the Pseudomonas aeruginosa recA gene cross-reacted with antibody raised against purified $E$. coli RecA protein. Based on this observation it was anticipated that the $L$. pneumophila RecA protein might also share immunological cross-reactivity with that of $E$. coli. Though expected (and observed), immunological cross-reactivity between the rec $A$ gene products of $L$. pneumophila and $E$. coli is of significant interest. As shown here and by others there is little or no detectable gene sequence homology (by Southern hybridization analyses) or restriction endonuclease cleavage patterns among the various cloned $r e c A$ genes, yet functionally they are highly conserved. Immunological cross-reactivity of $\operatorname{rec} A$ gene products is no doubt a reflection of the observed functional conservation. A comparison of $r e c A$ gene sequences is certainly warranted.

This work was initiated as a first step towards the construction of $\operatorname{rec} A$ strains of $L$. pneumophila by a gene replacement technique. Such strains will be invaluable in the long-term goals of characterizing the genetic organization of $L$. pneumophila. They will be most useful as recipients for plasmid-mediated chromosomal transfer experiments. Although marker transfer has been demonstrated, $\mathrm{R}^{\prime}$ structures were not isolated (Dreyfus \& Iglewski, 1985). Stabilization of $\mathrm{R}^{\prime}$ plasmids in a recA background will allow in vivo cloning of $L$. pneumophila genes. Additionally, the role of recombination in reversible avirulent conversion can be assessed. Finally, the $\operatorname{rec} A$ gene product of $E$. coli participates in a number of regulatory and catalytic processes. Conservation of heterologous $\operatorname{rec} A$ gene function in $E$. coli indicates that the RecA protein plays similar roles in other bacterial species. The rec $A$ gene is therefore a potentially good candidate for analysis of gene function and regulation in L. pneumophila.

This work was supported in part by a grant from the RGK Foundation and the American Lung Association of Texas and by Public Health Service grant AI24684-01A1. The expert technical assistance of Elisabeth Pipper is acknowledged and greatly appreciated.

\section{REFERENCES}

Adler, H. I., Fisher, W. D., COHEN, A. \& HARdiGREE, A. A. (1967). Miniature Escherichia coli cells deficient in DNA. Proceedings of the National Academy of Sciences of the United States of America 57, 321-326.

BERG, D. E. (1977). Insertion and excision of the transposable kanamycin resistance determinant Tn5. In DNA Insertion Elements, Plasmids and Episomes, pp. 205-212. Edited by A. I. Bukhari, J. A. Shapiro \& S. L. Adhya. Cold Spring Harbor, NY: Cold Spring Harbor Laboratory.

BetTeR, M. \& Helinski, R. (1983). Isolation and characterization of the $\operatorname{rec} A$ gene of Rhizobium meliloti. Journal of Bacteriology 155, 311-316.

Bolivar, F., Rodriguez, R. L., Greene, P. J., Betlach, M. C., HeYNeCKer, H. L., BoYeR, H. W., Crosa, J. H. \& Falkow, S. (1977). Construction and characterization of new cloning vehicles. II. A multipurpose cloning system. Gene 2, 95-111.
Boyer, H. W. \& Roulland-Dussolx, D. (1969). A complementation analysis of the restriction and modification of DNA in Escherichia coli. Journal of Molecular Biology 41, 459-472.

Brenner, D. J., Steigerwalt, A. G. \& McDade, J. E. (1979). Classification of the Legionnaires' disease bacterium: Legionella pneumophila, genus novum, species nova of the family Legionellaceae, familia nova. Annals of Internal Medicine 90, 656-658.

Brenner, D. J., Steigerwalt, A. G., Pohl, S., Behrens, H., Mannheim, W. \& Weaver, R. E. (1981). Lack of relatedness of Legionella pneumophila to Cytophagaceae, 'Pasteurellaceae' and Kingella. International Journal of Systematic Bacteriology 31, 89-90.

Chang, A. C. Y. \& Cohen, S. N. (1978). Construction and characterization of amplifiable multicopy DNA cloning vehicles derived from the p15A cryptic miniplasmid. Journal of Bacteriology 134, 1141-1156. 
Clark, A. J. (1973). Recombination-deficient mutants of $E$. coli and other bacteria. Annual Review of Genetics 7, 67-86.

Clewelt, D. B. \& Helinski, D. R. (1969). Supercoiled circular DNA-protein complex in Escherichia coli: purification and induced conversion to an open circular form. Proceedings of the National Academy of Sciences of the United States of America 62, 11591166.

Csonka, L. N. \& Clark, A. J. (1980). Construction of an $\mathrm{Hfr}$ strain useful for transferring $\mathrm{recA}$ mutations between $E$. coli strains. Journal of Bacteriology 143, 529-530.

Dreyfus, L. A. \& Iglewski, B. H. (1985). Conjugation-mediated genetic exchange in Legionella pneumophila. Journal of Bacteriology 161, 80-84.

EDELSTEIN, P. H. (1981). Improved semi-selective medium for isolation of Legionella pneumophila from contaminated clinical and environmental specimens. Journal of Clinical Microbiology 14, 298-303.

Elliot, J. A. \& Johnson, W. (1982). Virulence conversion of Legionella pneumophila serogroup-1 by passage in guinea pigs and embryonated eggs. Infection and Immunity 35, 943-946.

Finch, P. W., Brough, C. L. \& Emmerson, P. T. (1986). Molecular cloning of a recA-like gene of Methylotrophilus methylotrophus and identification of its product. Gene 44, 47-53.

Fliermans, C. B., Cherry, W. B., OrRison, L. H., Smith, S. D., Ticon, D. L. \& Pope, D. H. (1981). Ecological distribution of Legionella pneumophila. Applied and Environmental Microbiology 41, 9-16.

Geoghegan, C. M. \& Houghton, J. A. (1987). Molecular cloning and isolation of a cyanobacterial gene which increases the UV and methyl methanesulphonate survival of $\mathrm{rec} A$ strains of Escherichia coli K12. Journal of General Microbiology 133, 119-126.

Goldberg, I. \& MeKalanos, J. J. (1986). Cloning of the Vibrio cholerae recA gene and construction of a Vibrio cholerae recA mutant. Journal of Bacteriology 165, 715-722.

Goldberg, J. B. \& Ohman, D. E. (1984). Cloning and expression in Pseudomonas aeruginosa of a gene involved in the production of alginate. Journal of Bacteriology 158, 1115-1121.

Holmes, D. S. \& Quigley, M. (1981). A rapid boiling method for the preparation of bacterial plasmids. Analytical Biochemistry 114, 193-197.

Johnson, R. C., Yin, J. C. P. \& ReznikofF, W. S. (1982). Control of $\operatorname{Tn} 5$ transposition in $E$. coli is mediated by protein from the right repeat. Cell 30 , 873-882.

Jorgensen, R. A., Rothstein, S. J. \& Reznikoff, W. S. (1979). A restriction enzyme cleavage map of $\operatorname{Tn} 5$ and location of a region encoding neomycin resistance. Molecular and General Genetics 177, 65-72.

Keener, S. L., McNamee, K. P. \& McEntee, K. (1984). Cloning and characterization of $\operatorname{rec} A$ genes from Proteus vulgaris, Erwinia carotovora, Shigella flexneri, and Escherichia coli $\mathrm{B} / \mathrm{r}$. Journal of Bacteriology 160, 153-160.

KoKJOHN, T. A. \& Miller, R. V. (1987). Characterization of the Pseudomonas aeruginosa rec $A$ analog and its protein product: $r e c-102$ is a mutant allele of the $P$. aeruginosa PAO recA gene. Journal of Bacteriology 169, 1499-1508.
KoOmey, J. M. \& Falkow, S. (1987). Cloning of the recA gene of Neisseria gonorrhoeae and construction of gonococcal recA mutants. Journal of Bacteriology 169, 790-795.

LAEMMLI, U. K. (1970). Cleavage of structural proteins during the assembly of the head of bacteriophage T4 Nature, London 227, 680-685.

Maniatis, T., Frisch, E. F. \& SAMbrook, J. (1982). Molecular Cloning, a Laboratory Manual. Cold Spring Harbor, NY: Cold Spring Harbor Laboratory.

McDADE, J. E. \& ShePhaRd, C. C. (1979). Virulent to avirulent conversion of the Legionnaires' disease bacterium Legionella pneumophila: its effect on isolation techniques. Journal of Infectious Diseases 139, 707-711.

McEntee, K., Weinstock, G. M. \& Leman, I. R. (1979). Initiation of general recombination catalyzed in vitro by the recA protein of Escherichia coli. Proceedings of the National Academy of Sciences of the United States of America 76, 2615-2619.

OhMAN, D. E., WeSt, M. A., FlynN, J. L. \& GoldBerg, J. B. (1985). Method for gene replacement in Pseudomonas aeruginosa used in construction of recA mutants: recA independent instability of alginate production. Journal of Bacteriology 162, 1068-1074.

Roberts, J. W., Roberts, C. W. \& Craig, N. L. (1978). Escherichia coli gene product inactivates phage lambda repressor. Proceedings of the National Academy of Sciences of the United States of America 75, 4714-4718.

SANCAR, A., Stachelek, C., Konigsberg, W. \& Rupp, W. D. (1980). Sequences of the recA gene and protein. Proceedings of the National Academy of Sciences of the United States of America 77, 26112615.

Silhavy, T. J., Berman, M. L. \& Enquist, L. W. (1984). Experiments with Gene Fusions. Cold Spring Harbor, NY: Cold Spring Harbor Laboratory.

StougaARD, P. \& Molin, S. (1981). Vertical dyebuoyant density gradients for rapid analysis and preparation of plasmid DNA. Analytical Biochemistry 113, 191-193.

Stout, J., Yu, V. L., Vickers, R. M., ZuRAVlefF, J., Best, M., Brown, A., YeE, R. B. \& WadowsKy, R. (1982). Ubiquitousness of Legionella pneumophila in the water supply of a hospital with endemic Legionnaires' disease. New England Journal of Medicine 306, 466-468.

Thacker, W. L., Plikaytis, B. B. \& Wilkinson, H. W. (1985). Identification of 22 Legionella species and 33 serogroups with the slide agglutination test. Journal of Clinical Microbiology 21, 779-782.

Towbin, H., Staehelin, T. \& Gordon, J. (1979) Electrophoretic transfer of proteins from polyacrylamide gels to nitrocellulose sheets. Proceedings of the National Academy of Sciences of the United States of America 76, 4350-4354.

WALKER, G. C. (1984). Mutagenesis and inducible responses to deoxyribonucleic acid damage in Escherichia coli. Microbiological Reviews 48, 60-93.

Yanisch-Perron, C., Vieira, J. \& Messing, T. (1985). Improved M13 phage cloning vectors and host strains: nucleotide sequence of the $\mathrm{M} 13 \mathrm{mpl} 8$ and pUC19 vectors. Gene 33, 103-119. 